Original article

Received: 12 April 2017 / Accepted: 26 May 2017

\title{
INTENDED USE OF A BUILDING IN TERMS OF UPDATING THE CADASTRAL DATABASE AND HARMONIZING THE DATA WITH OTHER PUBLIC RECORDS
}

\author{
Małgorzata Buśko \\ Department of Integrated Geodesy and Cartography \\ AGH University of Science and Technology \\ Kraków, Poland
}

\begin{abstract}
According to the original wording of the Regulation on the register of land and buildings of 2001, in the real estate cadastre there was one attribute associated with the use of a building structure - its intended use, which was applicable until the amendment to the Regulation was introduced in 2013. Then, additional attributes were added, i.e. the type of the building according to the Classification of Fixed Assets (KST), the class of the building according to the Polish Classification of Types of Constructions (PKOB) and, at the same time, the main functional use and other functions of the building remained in the Regulation as well. The record data on buildings are captured for the real estate cadastre from other data sets, for example those maintained by architectural and construction authorities. At the same time, the data contained in the cadastre, after they have been entered or changed in the database, are transferred to other registers, such as tax records, or land and mortgage court registers. This study is the result of the analysis of the laws applicable to the specific units and registers. A list of discrepancies in the attributes occurring in the different registers was prepared. The practical part of the study paid particular attention to the legal bases and procedures for entering the function of a building in the real estate cadastre, which is extremely significant, as it is the attribute determining the property tax basis.
\end{abstract}

Keywords: real estate cadastre, legal procedures, function of the building, intended use of the building, changing function of the building

\section{Introduction}

The record data on buildings are captured for the real estate cadastre from other data sets, for example those maintained by architectural and construction authorities. At the same time, the data contained in the cadastre, after they have been entered or 
changed in the database, are transferred to other registers, such as tax records, or land and mortgage court registers.

The uniformity and semantic coherence within the applied terminology forms the basis for good cooperation of the authorities based on the legal regulations regarding various fields. This allows for the harmonization of the data in different public registers. Due to the need for interoperability and harmonization of the databases, it seems necessary that all the registers maintain a uniform and coherent terminology in the record data on building structures.

The thesis of this paper can be formulated in the following way: the current legal status does not provide for a sufficient correlation between the attributes of the building defining its intended purpose and the manner of its use, which function in the legislation governing various public registers in which this object - the building - is located.

Therefore, this paper will analyze the Polish legislation in terms of the applied terminology, definition and semantic coherence of the cadastral data concerning the manner of use of the building specified in the real estate cadastre as its attributes: the type according to the Classification of Fixed Assets (KST), the class according to the Polish Classification of Types of Construction (PKOB), the main function and other functions. The process and principles of determining the above attributes, as well as the scope of their use in registers will be analyzed, and the relationships between them will be determined.

\section{Current legal status}

Pursuant to Article 7d of the Geodetic and Cartographic Law (Act, 1989), the district governor is obliged, among other things, to maintain the Register of Land and Buildings $(\mathrm{EGiB})$ for the district area. This register, in accordance with Art. 4.1a.2) of the Geodetic and Cartographic Law may also be called the real estate cadastre. It is one of the spatial data sets of spatial information infrastructure, it should be established and maintained in the form of a database in the ICT system. Data sets kept in the databases, which include the real estate cadastre, should be up-to-date with interoperability ensured within the meaning of the Act on Spatial Information Infrastructure (Act, 2010). For this reason, the wording of legal acts should ensure that the relevant definitions and provisions are properly specified and that they are coherent and semantically unambiguous in the content of the various legal acts.

As far as building structures are concerned, Art. 20.1.2) of the Geodetic and Cartographic Law only generally specifies the necessary information to be obtained for the buildings, concerning "their location, intended purpose, utility function and general technical data". The detailing of this information, with the specification of the geometric and descriptive data, is carried out in the secondary legislation to the Geodetic and Cartographic Law, i.e. the Act of 2001 issued subject to Art. 26.2 of the Regulation on the Register of Land and Buildings (Regulation, 2001), amended by the amending Regulations in 2013 and subsequently in 2015.

Attention should be paid to the use of the term intended purpose regarding the building under the Geodetic and Cartographic Law, occurring independently of the term utility functions. The denotation of the intended purpose of the building is used in the Construction Law (Act, 1994) and in the secondary legislation to this Act. It does not, however, appear in the Register of Land and Buildings, nor is it anywhere explained, which attribute referred to in the surveying regulations should it be identified with. The Construction Law has cataloged the so-called categories of 
building structures, which do not occur in the legal regulations governing the surveying issues. In the context of this paper, it is important to distinguish between the categories for single family housing (Category I) and summer cottages (Category III). In the Regulation on the technical conditions to be met by buildings and their location (Regulation, 2002b), issued to the Construction Law, there is also a distinction in the definitions between the residential building ( $\$ 3.4$ of the Regulation) and the building for individual recreation (§3.7 of the Regulation).

According to the original wording of the Regulation on the Register of Land and Buildings of 2001, there was only one attribute related to the manner of use of the building in the real estate cadastre - utility function of the building. It was binding until 2013, until the entry into force of the amending Regulation on the Register of Land and Buildings. At that time, more attributes were added, i.e. the type of the building according to the Classification of Fixed Assets (KŚT), the class according to the Polish Classification of Types of Construction (PKOB), the main function and other functions.

It should be emphasized that both of these classifications associated with the new attributes of the building (KŚT and PKOB) derive from the secondary legislation to the Act on Public Statistics (Act, 1995). Currently, the Regulation on KŚT of 3 October 2016, issued pursuant to Art. 40 section 2 of the Act on Public Statistics, is binding (Regulation, 2016b). This Regulation repealed its previous version of 2010, and its content has changed significantly. The new Regulation on the Classification of Fixed Assets contains a new definition of the building, which differs from the definition contained in the Construction Law (Act, 1994), whereas the Regulation on the Polish Classification of Types of Construction (PKOB), issued pursuant to the same article of the Act on Public Statistics of 1999 (Regulation, 1999), was amended in some respects by the amending regulation of 12 February 2002 (Regulation, 2002a). The Regulation on the Polish Classification of Types of Construction (PKOB) contains the definition of the building which is identical to that in the current regulation on the KŚT, i.e. not related to the definition contained in the Construction Law.

Moreover, the current versions of the Regulations on KŚT and PKOB also contain the definitions of the residential building and non-residential building, determining the basic subdivision of building structures into sections (section 11 - residential buildings, section 12 - non-residential buildings). According to their wording, the classification of the building to a particular section is determined by the role of the prevailing usable floor space of the building:

"Residential buildings are building structures with at least half of the total usable floor space used for residential purposes. In the cases where less than half of the total usable floor space is used for residential purposes, such a building is classified as non-residential according to its intended purpose".

"Non-residential buildings are building structures used mainly for non-residential purposes. The subdivision of building structures into residential and non-residential ones in the Classification of Fixed Assets was based on the Polish Classification of Types of Construction (PKOB) ..."

"The classification of the building (premises) to the proper subgroup and type is determined by its intended purpose and the associated construction and equipment, and not by the manner of its use, which in practice happens to be inconsistent with its intended purpose”. (Regulation, 2016), (Regulation, 1999). 
However, the very fact of calculating the usable floor space of the building, not specified in the laws governing surveying issues, is frequently a problem, as demonstrated in (Buśko, 2015).

To summarize, in the legislative acts there are different definitions of the building one contained in the Act on Public Statistics and the regulations to it, another in the Construction Law and the regulations to it. The surveying regulations refer to the Act on Public Statistics in this respect. This results in the inconsistency in the applied terminology which occurs when the authority maintaining the real estate cadastre updates the database subject to the documentation provided by the architectural and construction authorities. Another adverse effect of these uncorrelated definitions of the building and its attributes is visible when the tax authorities use the data from the real estate cadastre. Article 1a.1.1) of the Act on Local Taxes and Fees (Act, 1991) provides for a definition of the building, in the wording consistent with the wording of the Construction Law, and therefore inconsistent with the surveying regulations.

In order to summarize the above considerations, a diagram of consistency and inconsistency of the definitions of the building, found in the key legislative acts, has been developed (Fig. 1).
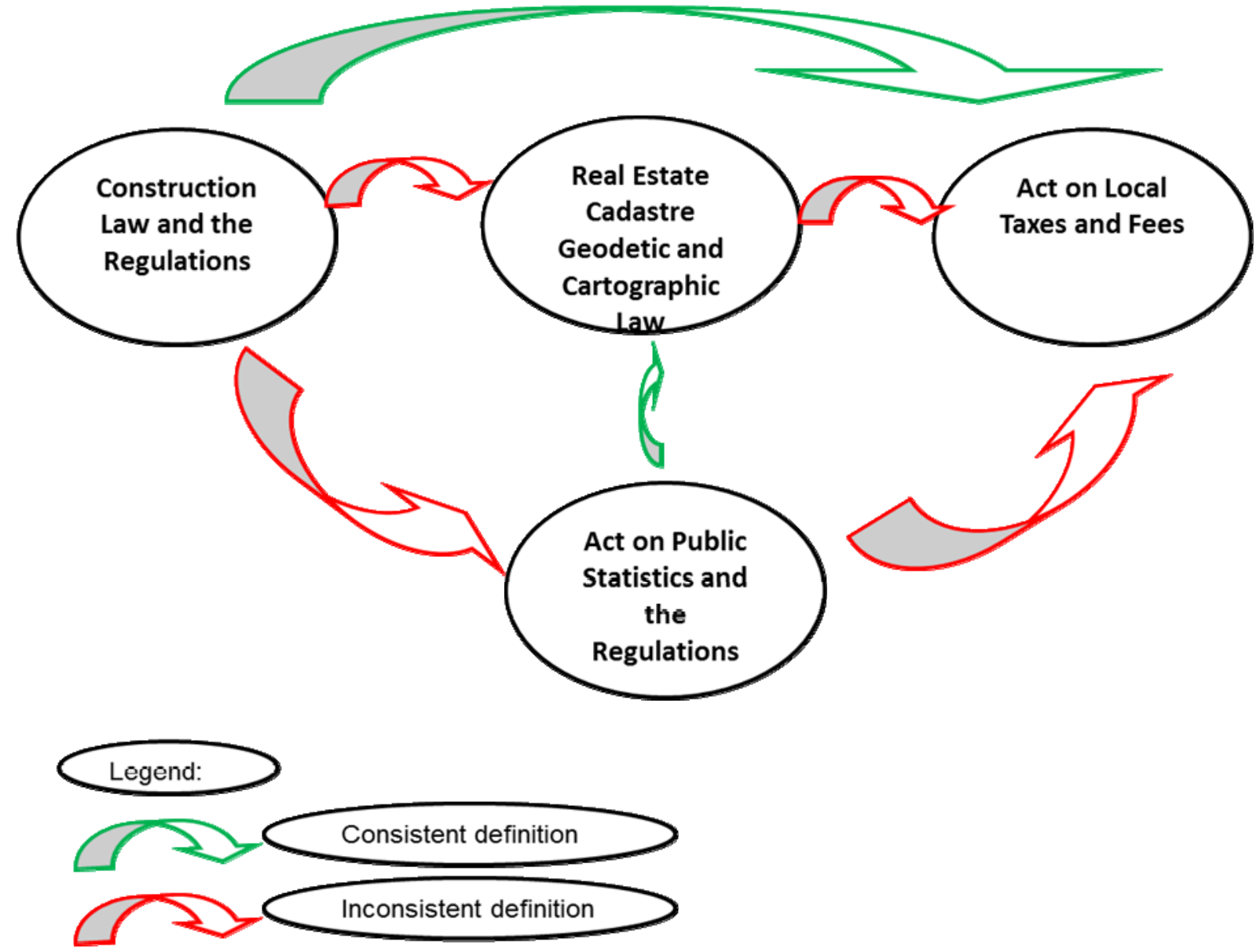

Fig. 1. Degree of consistency of the definitions of the building in the legislative acts

The issues related to the entering of the building into the cadastral database have been the subject of numerous interesting papers, some of which concerned the changes in the attributes over the years, due to the changing law (Lawendowicz, 2017), circulation of the documentation in the geodetic and cartographic documentation centers (Hanus, 2011), or the analysis of the definitions used in the 
real estate cadastre (Hanus et al., 2013a, 2013b; Mika, 2016). The issues concerning building structures, however, were mainly analyzed in terms of geometric data. Some of these papers refer to the object: the building (Krzyżek, 2015), others analyze the topological inconsistency between buildings and record parcels in the database (Inglot and Koziol, 2016; Biłozor \& Renigier-Biłozor, 2016). Some studies confirm the occurrence of the differences between the geodetic database application model and the target model, as illustrated on the example of the record of utilities network in (Balawejder et al., 2016). All these inconsistencies restrict the possibility to exchange data without modification, which is in discordance with the findings of the INSPIRE directive.

The article (Aien et al., 2015) is presented Building Information Models (e.g., IFC) and virtual 3D city models (e.g., CityGML). The main focus of these models is on the physical and functional characteristics of urban properties and facilities, which neglects the legal and ownership aspects. (Çağdaş, 2013) also developed an ADE to CityGML to support the requirements of the immovable property taxation system in Turkey. (Isikdag et al., 2014) explored the possible role of semantically rich 3D building models and 3D cadastres in relation to valuation and taxation.

\section{Materials and methods}

\subsection{The mode of current update of the real estate cadastral database}

The task of the district governor, who is the authority maintaining the register of land and buildings, is to keep the real estate cadastral database updated. The governor can introduce changes in the form of the current update of the cadastre or through the modernization of the records. The distinction between these two modes is extremely important in terms of the attributes which define the manner of use of the building structure. It should be remembered that, in accordance with the letter of law and with the established line of judicial decisions, the register of land and buildings is a public register. It was stated that the authority maintaining the register of land and buildings should only make records of the legal status, determined in other procedures or by other adjudicating authorities (Judgments, 2012; 2013; 2016). Therefore, the entries made into the real estate cadastre should only reflect the existing legal status rather than create a new legal status. This means that it is only allowed to enter into the cadastre these data which were documented and submitted to the authority maintaining the cadastre, or obtained by the authority from other registers.

In the case when the information necessary for the updating of the cadastre is not possible to be captured otherwise, the district governor may apply Art. 22.3 of the Geodetic and Cartographic Law, to demand information on the manner of use of the building.

Pursuant to Art. 24.2a of the Geodetic and Cartographic Law, the current updating of the cadastral data in relation to the discussed attributes of the building structure, may be conducted ex officio or at the request of a party. The diagram (Fig. 2) illustrates the method of updating by means of material and technical procedure. In the current cadastral database update, the initiative is not on the part of the district governor. The governor takes action ex officio or at the request of the party only if the appropriate documentation that will form the basis for the change is submitted. An exception to this rule is the possible correction of erroneous data, if the error is due to earlier actions of the authority. 


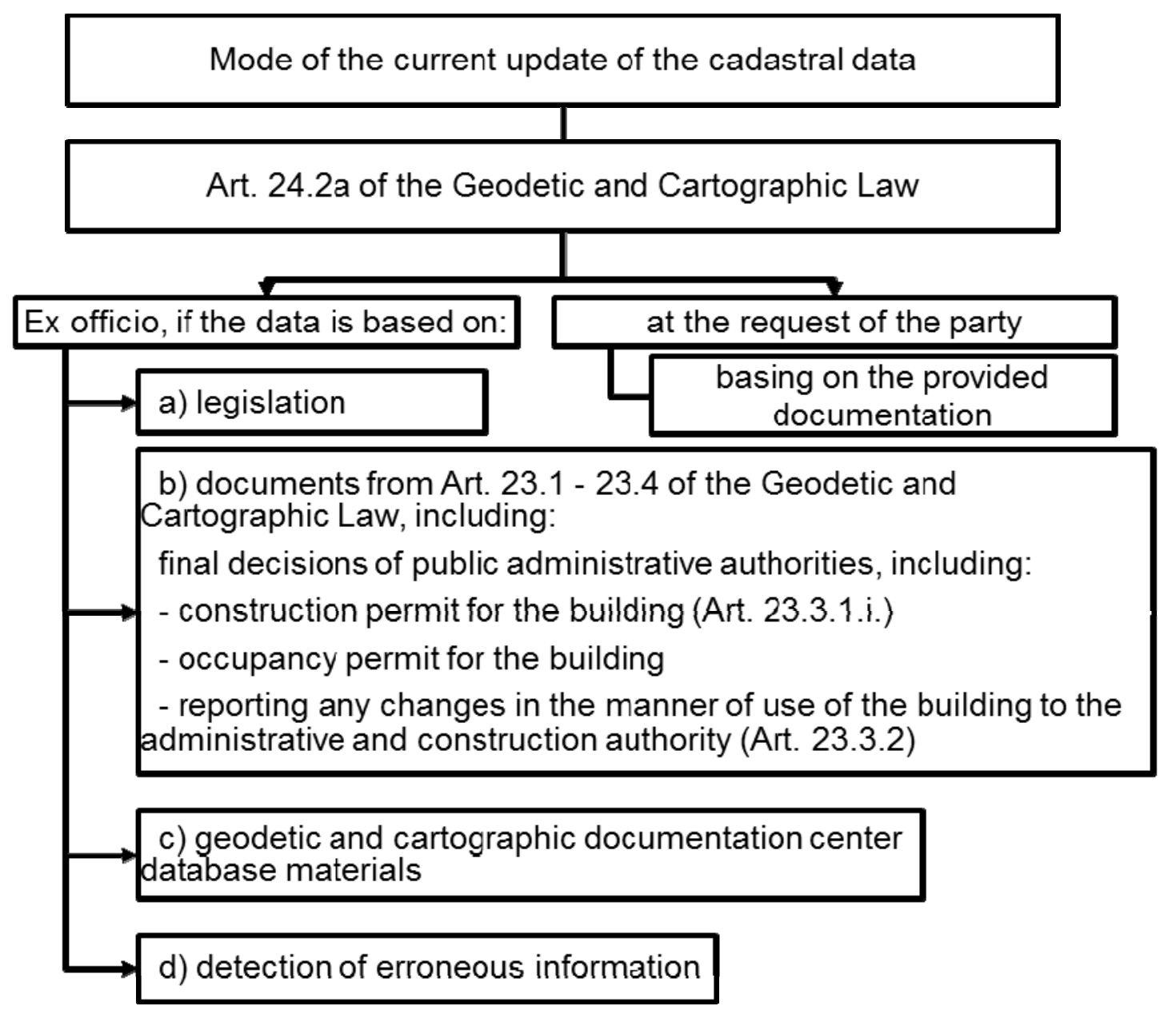

Fig. 2. Update of the cadastral data by means of material and technical procedure.

According to the currently binding provisions on the Register of Land and Buildings, the building should already be entered into the cadastral database if it has status 4 - in design (Fig. 3). The authority responsible for maintaining the Register of Land and Buildings should do so basing on the final building permit.

\begin{tabular}{|l|}
\hline \multicolumn{1}{|c|}{ «Enumeration» } \\
EGB_StatusBudynku \\
\hline wybudowany $=1$ \\
wBudowie $=2$ \\
budynekDoRozbiork $=3$ \\
projektowany $=4$
\end{tabular}

Fig. 3. Record -Status of the building

Source: Appendix to the Register of Land and Buildings of 2013

Pursuant to §63.f. of the Regulations on the Register of Land and Buildings, for each building it is obligatory to enter at least the following attributes:

- building identification,

- building status,

- geometric description of the contour of the building, or - in the absence of the data necessary to prepare such a description - the data determining the location of the geometric center of the building in the 2000 system,

- type of the building according to the Classification of Fixed Assets, 
- class of the building according to the Polish Classification of Types of Construction (v),

- the main function of the building (v).

It should be noted, however, that the class of the building according to the Polish Classification of Types of Construction and the main function of the building have a voidable (v) stereotype, which will only provide information on the reasons why the element is void and how it could be acquired in the future.

\subsection{Update of the real estate cadastral database basing on the documentation of the architectural and construction authorities, entering a new building}

Unfortunately, the terms used in the building regulations are not completely consistent with those used in geodetic regulations. Regarding the analyzed attributes of the building, the Construction Law provides for the description of the function of the building structure with reference to the architectural and construction project, but in the further provisions, the term the manner of use of the building structure is used. Both of these terms were previously identified with the utility function of the building as the only attribute of this kind occurring in the real estate cadastre until 2013. However, at present, when the obligatory attributes in the real estate cadastre include the type of the building according to the Classification of Fixed Assets (KST), the class according to the Polish Classification of Types of Construction (PKOB), and the function, it is not known what the function and the manner of use should be identified with in the building regulations. In the building permits, this function does not always occur, nor is it cataloged anywhere in the building regulations. In the terminology used in the decisions of the architectural and construction authorities, a definition of the category of the building structure, which is clearly defined and cataloged in the Appendix to the Construction Law, occurs much more frequently. However, there is no coherence between these categories of building structures, the type of the building according to the Classification of Fixed Assets and the class according to the Polish Classification of Types of Construction in the legislation governing public statistics, or the function of the building from the geodetic law. It is, therefore, a question to be asked whether and how the authority maintaining the Register of Land and Buildings is able to refer this terminology to the attributes of the building required for it to be entered into the cadastre?

It will be exemplified by a building permit decision which refers to the investment a warehouse building with office space, defined as the object of category XVIII (Fig. 4). This building is therefore considered as one building object and has been unambiguously categorized into a particular category. The building permit does not mention any of the building attributes used in the real estate cadastre. There are no values for the usable floor space of the building to be included in the warehouse part or the office space part, either.

Basing on the building permit only, the authority maintaining the Register of Land and Buildings is not able to determine with absolute certainty the class of the building which, according to the Regulation on the Register of Land and Buildings, forms the basis for determining the following attributes: the type of the building according to the Classification of Fixed Assets and the function of the building. Warehouse buildings are defined by both different type and class (type 104 and class 1252) than office buildings (type 105 and class 1220). 


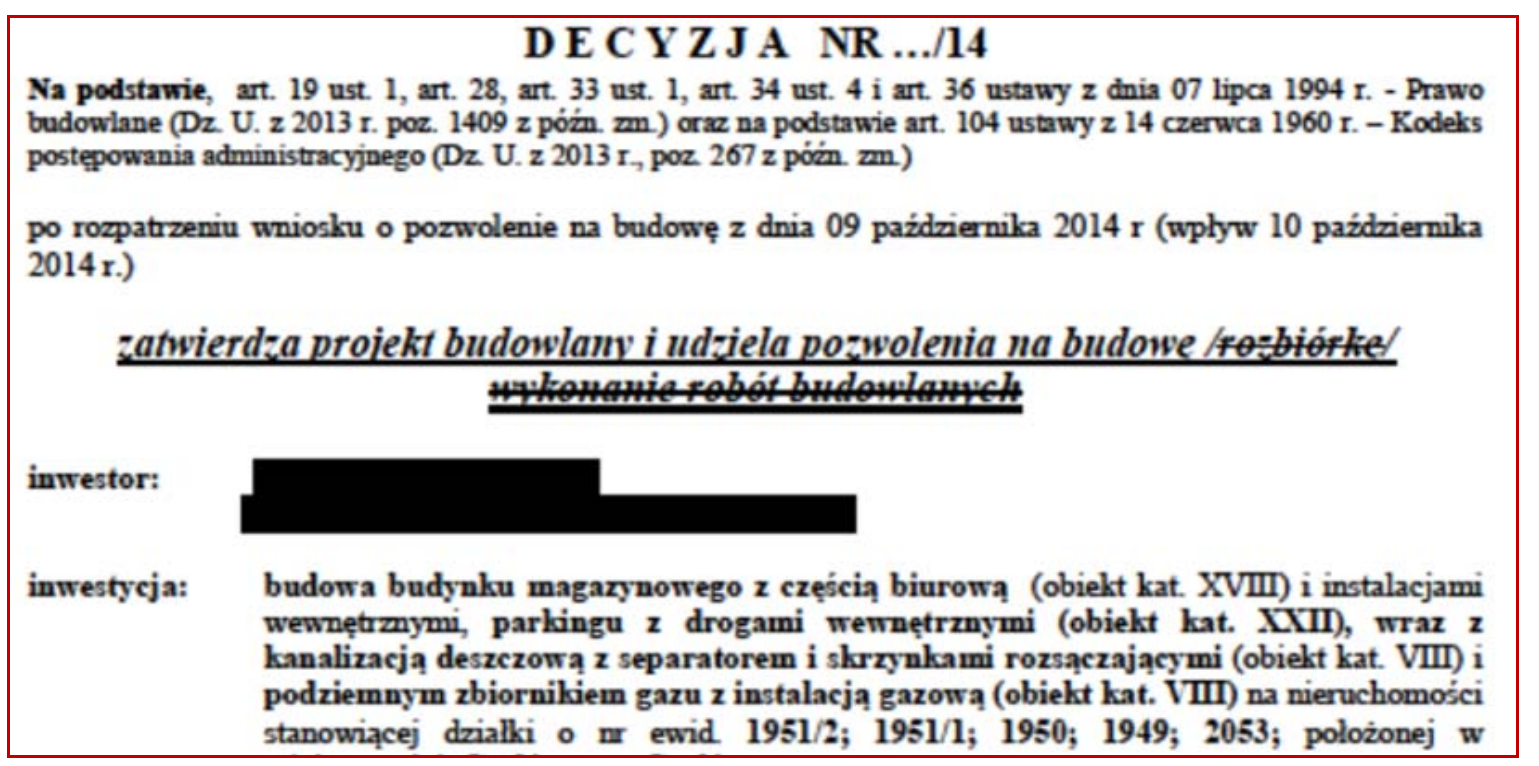

Fig. 4. Construction permit decision

Therefore, in order to determine the type and class of the building, it is necessary to know the values of its usable floor space covered by this diversified use. A certain clue in this regard is qualifying the building to the category XVIII which, in accordance with the Construction Law, includes warehouse facilities. However, the assurance can be gained only after the analysis of the construction design, which should include the data on the usable floor space of the building. If the project demonstrates that the prevailing part of the building will be used as a warehouse, the following attributes will be entered for the building:

- The type according to the Classification of Fixed Assets - 104 (tanks, silos and storage buildings),

- The class according to the Polish Classification of Types of Construction 1252 (tanks, silos and storage buildings),

- Main function - 1252.Mg (warehouse).

However, if the project revealed that the prevailing floor area of the building would be used as an office space, then the class of the building would be 1220 (office buildings) followed by the type 105 (office buildings); then what is left is to determine the utility function. Within the class 1220 , there are 21 possible functions available in the glossary of the Regulation on the Register of Land and Buildings. In order to specify the function, it is necessary to have knowledge of the type of this office space, since the function office (without additional extension) is not included in the glossary. In conclusion, it should be noted that construction designs frequently do not include a specification of the usable floor space covered by diversified use. Thus, a question arises as to whether the authority maintaining the Register of Land and Buildings is entitled to analyze the content of a construction design, to make calculations of the surface, or to specify the floor space intended for diversified uses?

\subsection{Determining the class of the building basing on the data from the construction design}

The previous chapter proves that when a new building is entered into the real estate cadastre, a building permit is not enough, since it is impossible to determine the 
usable floor space therefrom. The geodetic administration authority must therefore analyze the content of the construction design. It forms the basis to calculate the floor space of the building intended for diversified uses. Another example will illustrate the effect of applying the legal provisions when determining the attributes for the building which includes diversified parts in terms of their intended purpose and use (Table 1).

Table 1. Determining the attributes for the building with diversified uses. Source: own study based on (Regulation, 2002a; Regulation, 2016b; Regulation, 2001)

\begin{tabular}{|c|c|c|c|c|c|}
\hline $\begin{array}{l}\text { Type of use of } \\
\text { the part of the } \\
\text { building }\end{array}$ & $\begin{array}{l}\text { Percentage of } \\
\text { total usable } \\
\text { floor space }\end{array}$ & $\begin{array}{l}\text { Class acc. to } \\
\text { the Polish } \\
\text { Classification } \\
\text { of Types of } \\
\text { Construction } \\
\text { (PKOB) }\end{array}$ & $\begin{array}{l}\text { Class acc. to } \\
\text { the Polish } \\
\text { Classification } \\
\text { of Types of } \\
\text { Construction } \\
\text { (PKOB) }\end{array}$ & \begin{tabular}{|} 
Type acc. to \\
the \\
Classification \\
of Fixed \\
Assets \\
(KŚT)
\end{tabular} & $\begin{array}{c}\text { Main } \\
\text { function }\end{array}$ \\
\hline 3 apartments & $40 \%$ & 1122 & $\begin{array}{l}\text { Section } 1 \\
\text { Buildings } \\
\text { Division } 12 \\
\text { Non-residential } \\
\text { buildings } \\
\\
\text { Group } 126 \\
\text { Public cultural } \\
\text { facilities, } \\
\text { educational } \\
\text { facilities or } \\
\text { hospitals and } \\
\text { buildings of } \\
\text { medical care } \\
\text { institutions }\end{array}$ & $\begin{array}{l}\text { Group } 1 \\
\text { Buildings and } \\
\text { premises (...) } \\
\text { Subgroup } 10 \\
\text { Non- } \\
\text { residential } \\
\text { buildings } \\
\text { Type } 107 \\
\text { Educational, } \\
\text { science and } \\
\text { cultural } \\
\text { facilities as } \\
\text { well as sports } \\
\text { facilities }\end{array}$ & $\begin{array}{l}\text { 1262.BI } \\
\text { Library }\end{array}$ \\
\hline $\begin{array}{c}\text { Bureau of } \\
\text { Ioan institution }\end{array}$ & $10 \%$ & 1220 & Class 1262 & & \\
\hline $\begin{array}{l}\text { Retail outlets } \\
\text { and pharmacy }\end{array}$ & $10 \%$ & 1230 & $\begin{array}{l}\text { Museums and } \\
\text { libraries }\end{array}$ & & \\
\hline Library & $30 \%$ & 1262 & & & \\
\hline $\begin{array}{c}\text { Doctor's } \\
\text { office }\end{array}$ & $10 \%$ & 1264 & & & \\
\hline
\end{tabular}

Most of the usable floor space of the analyzed building is occupied by non-residential elements $(60 \%)$, therefore, according to the Polish Classification of Types of Construction, the entire building should be classified as non-residential. It should be assigned the class 1262, because within the non-residential part this class is predominant $(30 \%)$. These findings of the class should be followed by the group, subgroup and type, according to the classification scheme set out in the Regulation on the Classification of Fixed Assets. This Regulation specifies the association between the Classification of Fixed Assets and the Polish Classification of Types of Construction, and the type should be defined as 107 therefrom. In order to determine 
the main function, the glossary in the Regulation on the Register of Land and Buildings should be used, where possible functions of buildings are cataloged as part of the classes. As demonstrated in Table 1, despite the fact that the residential units occupy the larger part of the usable floor space $(40 \%)$ than the library $(30 \%)$, the main function of the building should be defined as 1262.Library, because it should be derived from the glossary entries contained within a specific class of the building. This, however, is in some contradiction to the definition of the utility function contained in the Regulation on the Register of Land and Buildings, which is defined as: "the manner of use of the prevailing usable floor space of the building". According to this definition, the prevailing usable floor space in this building is used as three apartments, and therefore if applying the literal definition of the utility function, it should be defined as 1122.Dw (Multi-Family Building). However, according to the glossary of the Regulation on the Register of Land and Buildings, the main function of this building (due to its class according to the Polish Classification of Types of Construction) is defined as 1262.Bl (Library), which leads to some sort of a paradox. It is possible to imagine that it will not be easy to explain this scheme to the building owner and justify the decision taken by the authority.

\section{Results - exchange of the record data between the registers according to the Regulation on the Integrated Real Estate Information System}

Due to the implementation of the Integrated Real Estate Information System (ZSIN) in Poland, the Regulation on ZSIN issued subject to Article 24b section 4 of the Geodetic and Cartographic Law (Regulation, 2013a) includes the UML application schemes, according to which the record data should be exchanged between the following registers: land and buildings register, tax authorities, courts maintaining land and mortgage registers, or registries of property prices and values. Appendix 3 to the Regulation on the Integrated Real Estate Information System contains the notifications of changes to the record data entered into the real estate cadastre and the XML scheme of these notifications.

Appendix 3 to this Regulation defines the utility function of the building as referred to in Appendix 1a to the Regulation on the Register of Land and Buildings: „the main function of the building shall be understood as the manner of its use in the prevailing part of the usable floor space of this building".

The analysis will demonstrate which of the record data of the building related to the form of its use is relevant to other databases and should be transferred, in accordance with the Regulation on the Integrated Real Estate Information System.

\subsection{Tax authorities}

Article 6.3 of the Tax Act (Act, 1991) provides for the change in the manner of use of a taxable object or its part: "If during a tax year there has been an event affecting the amount of taxation in that year, and in particular a change in the manner of use of that taxable object or part thereof, the tax is reduced or increased, starting from the first day of the month following the month in which the event occurred".

This provision was already formulated in the original version of the Act of 1991, and remained after the last amendment in 2016. It seems therefore that the legislator was referring here to the utility function of the building as the only attribute which characterized the manner of use of the building until the introduction of the Regulation amending the Regulation on the Register of Land and Buildings in 2013. 
At this point, the question arises as to which of these three attributes should be binding for the tax authority after the introduction of new legislation. In order to resolve this issue, fragments of the notification of changes in the record data will be quoted from the Appendix to the Regulation on the Integrated Real Estate Information System (ZSIN), transferred from the real estate cadastre (KN) to the tax authority (Fig. 5). It states that the tax authorities are to be notified of the type of the building according to the Classification of Fixed Assets, and of the class according to the Polish Classification of Types of Construction. Under the ZSIN regulation, the information on the utility function of the building is superfluous, although almost all the other attributes specified in $\$ 63$ of the Regulation on the Register of Land and Buildings have been included in this notification.

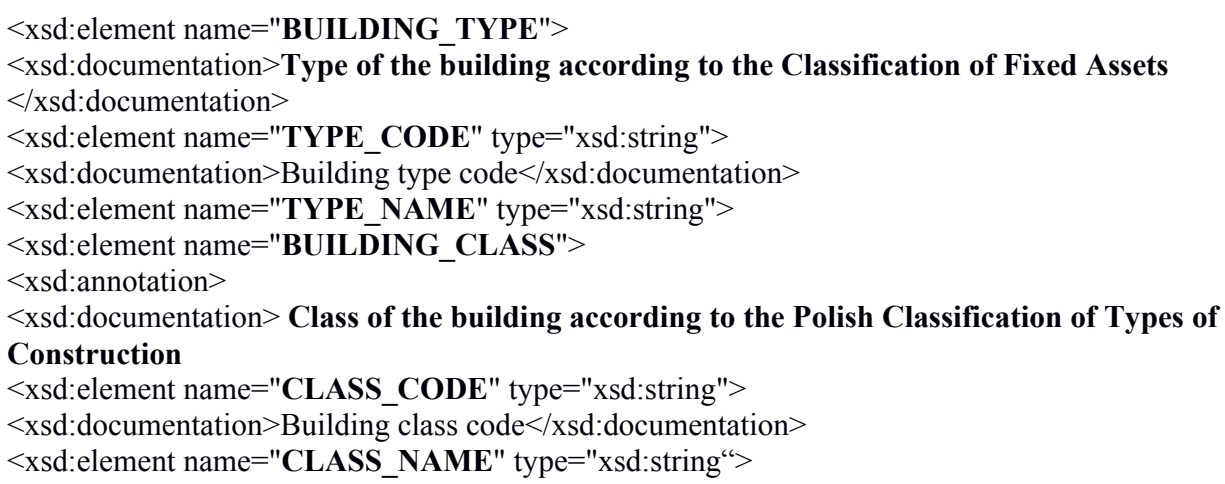

Fig. 5. Notification of the changes in the real estate cadastre to the tax authorities under the ZSIN Regulation

To sum it up, a conclusion can be drawn that in the process of exchanging the data between the real estate cadastre and the tax authority, until the adoption of the amending Regulation on the Register of Land and Buildings in 2013:

\section{$\underline{\text { manner of use }=\text { utility function of the building }}$}

After the amendment of the Regulation on the Register of Land and Buildings in 2013 and in accordance with the Regulation on the Integrated Real Estate Information System:

manner of use $=$ type acc. to the Classification of Fixed Assets + class acc. to the Polish Classification of Types of Construction

\subsection{District courts maintaining land and mortgage registers}

In order to determine which of the three currently binding attributes for the building will be relevant from the point of view of the entry into the land and mortgage registers, it is necessary to quote from the Regulation of the Minister of Justice of 21 November 2013 on the establishment and maintenance of land and mortgage registers in the IT system (Regulation, 2013b). This Regulation was repealed in 2015 by the Act amending the Code of Civil Procedure and some other laws (Act, 2015). It was replaced by the Regulation of 15 February 2016 on the establishment and maintenance of land and mortgage registers in the IT system (Regulation, 2016a), 
published in the Journal of Laws on March 11, 2016, i.e. one year after it had been established. In Section 3 of the previous wording of the Regulation of 2013, §22.2) stated:

h) 1.4.2.8 "intended purpose of the building" - denotation of the utility function of the building according to the data in the Register of Land and Buildings".

In the current wording of the Regulation, this provision has been amended and in the current Regulation, in Section 3, §20.2 is as follows:

\section{h) 1.4.2.8 "intended purpose of the building" - the type of the building according} to the Classification of Fixed Assets in accordance with the data in the Register of Land and Buildings".

However, due to the amendment of the Regulation on the establishment and maintenance of land and mortgage registers in the IT system, an ambiguity occurred in the ZSIN Regulation of 2013. In the application scheme of the notification of the changes in the land and mortgage register transferred to the real estate cadastre, the term which is still referred to is: The intended purpose of the building (denotation of the utility function of the building), as demonstrated in Figure 6.

<xsd:element name="BUILDING" minOccurs="0" maxOccurs="unbounded">

<xsd:element name="INTENDED_PURPOSE" type="xsd:string" minOccurs="0">

$<$ xsd:annotation>

$<x$ d:documentation>

intended purpose of the building (denotation of the utility function of the building)

Fig. 6. Notification of the changes in the land and mortgage register to the real estate cadastre under the ZSIN Regulation

In the opposite direction, in the notification of the changes in the real estate cadastre transferred to the district court, there is: "Type of the building according to the Classification of Fixed Assets", as demonstrated in Figure 7.

<xsd:element name="BUILDING TYPE">

$<x s d$ :documentation>Type of the building according to the Classification of Fixed Assets

$<$ xsd:element name="TYPE_CODE" type="xsd:string">

$<x$ sd:documentation>Building type code $</ x$ sd:documentation $>$

$<x$ sd:element name="TYPE_NAME" type="xsd:string">

$<x s d$ :documentation>Building type name</xsd:documentation>

Fig. 7. Notification of the changes in the real estate cadastre to the land and mortgage register under the ZSIN Regulation

In conclusion, it should be stated that in the Regulation on the Integrated Real Estate Information System (ZSIN), for the direction of the information flow from the land and mortgage registers $(\mathrm{KW})$ to the real estate cadastre $(\mathrm{KN})$, the intended purpose of the building is identified with its utility function, whereas in the opposite direction, from the real estate cadastre to the land and mortgage registers, the purpose of the building is identified with its type according to the Classification of Fixed Assets: 


\section{from $\mathrm{KW}$ to $\mathrm{KN}$ :}

intended purpose of the building = utility function of the building

\section{from $\mathrm{KN}$ to $\mathrm{KW}$ :}

type acc. to the Classification of Fixed Assets = intended purpose of the building

Therefore, it is essential to urgently amend the ZSIN Regulation in order to eliminate the inconsistency of the terminology identified therein with the Regulation on the establishment and maintenance of land and mortgage registers in the IT system, which entered into force in 2016.

\section{Discussion}

In order to conclude which of the building attributes from $\S 63.4$ - $\$ 63.6$ of the Regulation on the Register of Land and Buildings will be subjected to an exchange with other registers after the introduction of the Integrated Real Estate Information System (ZSIN), Table 2 contains the data from the notifications between the registers, according to the Appendix to the ZSIN Regulation.

Table 2. Selected record data of the building, transferred between the registers according to the ZSIN Regulation.

\begin{tabular}{|c|c|c|c|c|}
\hline \multirow[b]{2}{*}{$\begin{array}{c}\text { ATTRIBUTE } \\
(+) \text { occurs } \\
\text { (-) does not occur }\end{array}$} & \multicolumn{4}{|c|}{ Direction of notification } \\
\hline & $\begin{array}{c}\text { from the real } \\
\text { estate } \\
\text { cadastre to the } \\
\text { tax authorities }\end{array}$ & $\begin{array}{l}\text { from the } \\
\text { real estate } \\
\text { cadastre to } \\
\text { land and } \\
\text { mortgage } \\
\text { registers }\end{array}$ & $\begin{array}{l}\text { from land } \\
\text { and } \\
\text { mortgage } \\
\text { registers to } \\
\text { the real } \\
\text { estate } \\
\text { cadastre }\end{array}$ & $\begin{array}{c}\text { from the } \\
\text { real estate } \\
\text { cadastre to } \\
\text { the register } \\
\text { of property } \\
\text { prices and } \\
\text { values }\end{array}$ \\
\hline $\begin{array}{l}\text { \$63.1.4) } \\
\text { Type of the building } \\
\text { acc. to } \\
\text { the Classification of } \\
\text { Fixed Assets (KST) }\end{array}$ & 4) & 4) & 4) & 4) \\
\hline $\begin{array}{c}\text { \$63.1.5) } \\
\text { Class of the building } \\
\text { acc. to the Polish } \\
\text { Classification of Types } \\
\text { of Construction } \\
\text { (PKOB) }\end{array}$ & 5) & 5) & 5) & 5) \\
\hline $\begin{array}{c}\text { §63.1.6) } \\
\text { Main function } \\
\text { Other functions }\end{array}$ & $\begin{array}{l}6) \quad- \\
\text { (main) } \\
6 \text { ) - } \\
\text { (other) }\end{array}$ & $\begin{array}{l}\text { 6) - } \\
\text { (main) } \\
6 \text { ) - } \\
\text { (other) }\end{array}$ & $\begin{array}{l}6) \quad+ \\
\text { (main) } \\
6 \text { ) - } \\
\text { (other) }\end{array}$ & $\begin{array}{l}6)+ \\
\text { (main) } \\
6 \text { ) }+ \\
\text { (other) }\end{array}$ \\
\hline
\end{tabular}

From the information contained in Table 2 it appears that these attributes will be used in a limited and completely irregular manner in the communication between the analyzed registers. 


\section{Conclusions}

The issues related to the legal bases of entering, in particular, the changes in the utility function of the building into the real estate cadastre, were discussed in detail in the paper (Buśko, 2014). This study is mainly concerned with those issues with respect to new buildings as well as their exchange with other authorities, registers and data sets.

For new buildings entered into the real estate cadastre after 2013, the only source of the data on the manner of their use should be the architectural and construction documentation in the form of a building permit, together with the construction design and the construction supervision documentation in the aspect of changing the intended use of the building. Only such documents should provide the bases for supplying the database of the Register of Land and Buildings with the data on the attributes associated with its use.

In the new urban planning and construction code, it would be advisable to order the architectural and construction authorities to use the terminology which is in accordance with the regulations issued under the Public Statistics Act (Regulation on the Classification of Fixed Assets, Regulation on the Polish Classification of Types of Construction), and which is also used by surveying administrative authorities.

In the conclusion of the considerations regarding the type, class and utility function of the building, it can be stated that, in accordance with the provisions of the Regulation on the Register of Land and Buildings in its original version of 2001, the utility function, as the only attribute describing the manner of use of the building at that time, was associated with the Regulation on the Classification of Fixed Assets. To put it simply, it can be stated that for the buildings entered into the real estate cadastre before the end of 2013 , it is identical with the current type of the building according to the Classification of Fixed Assets.

Table 2 demonstrates that the attribute defined as the main function of the building according to the Regulation on the Integrated Real Estate Information System (ZSIN) will not be transferred either to the tax authorities or to the courts maintaining land and mortgage registers. Therefore, it might be advisable to consider deleting this attribute from the real estate cadastre and leaving only the attributes: the type of the building according to the Classification of Fixed Assets (KŚT) and the class according to the Polish Classification of Types of Construction (PKOB). Such a limitation of the attributes would result in greater clarity in the cadastral database and would eliminate the paradoxes occurring in the present legal status, as presented in this paper.

In the current legislation related to the real estate cadastre, there are numerous unspecified and sometimes mutually contradictory provisions. This results in the inconsistencies on the national scale, both in the decisions taken by the geodetic and cartographic authorities and in the surveyors' activities.

As a result of the 2015 amendment to the Regulation on the establishment and management of land and mortgage registers in the IT system, and the introduction of a provision that the intended purpose of the building determines its type according to the Classification of Fixed Assets, it is urgent to amend the ZSIN Regulation and the application schemes contained therein, used for transferring the data from the land and mortgage registers to the real estate cadastre.

In the enacted legislative acts governing the branches between which there will be the exchange of cadastral records and information on cadastral objects, especially on buildings, it is important to ensure the uniformity of the terminology used, to formulate 
the definitions of the objects and attributes and their semantic coherence. In the current legislation such coherence is not preserved.

\section{Acknowledgement}

This work has been done as a part of scientific research carried out in Department of Integrated Geodesy and Cartography 11.11.150.444

\section{References}

Act (1982) of 6 July 1982 on land and mortgage registers. Journal of Laws of 1982, No. 19, item 147, as amended.

Act (1989) of 17 May 1989 Geodetic and cartographic law. Journal of Laws of 1989, No. 30, item 163, as amended.

Act (1991) of 12 January 1991 on Local Taxes and Fees. Journal of Laws of 1991, No. 9, item 31, as amended.

Act (1994) of 7 July 1994 Construction Law. Journal of Laws, item 290, as amended.

Act (1995) of 29 June 1995 on Public Statistics. Journal of Laws of 1995, No. 88, item 439, as amended.

Act (2015) of 15 January 2015 amending the Act - the Code of Civil Procedure and some other acts, Journal of Laws of 2015, No. 0, item 218.

Regulation (1999) of the Council of Ministers of 30 December 1999 on the Polish Classification of Types of Construction (PKOB), Journal of Laws of 1999, No. 112, item 1316.

Regulation (2001) of the Minister of Regional Development and Construction of 29 March 2001 on the Register of Land and Buildings. Journal of Laws of 2001, No. 38 , item 454, as amended.

Regulation (2002a) of the Council of Ministers of 12 February 2002 amending the Regulation on the Polish Classification of Types of Construction (PKOB). Journal of Laws of 2002, No. 18, item 170.

Regulation (2002b) of the Minister of Infrastructure of 12 April 2002 on technical conditions to be met by buildings and their location. Journal of Laws of 2015, item 1422, as amended.

Regulation (2013a) of the Council of Ministers of 17 January 2013 on the Integrated Real Estate Information System. Journal of Laws of 2013, item 249.

Regulation (2013b) of the Minister of Justice of 21 November 2013 on the establishment and maintenance of land registers in the IT system, Journal of Laws of 2013 , item 1411.

Regulation (2016a) of the Minister of Justice of 15 February 2016 on the establishment and maintenance of land registers in the IT system, Journal of Laws of 2016, item 312.

Regulation (2016b) of the Council of Ministers of 3 October 2016 on the Classification of Fixed Assets (KŚT), Journal of Laws of 2016, item 1864.

Judgment (2012) of the Provincial Administrative Court in Bialystok, II SA Bk 52/12.

Judgment (2013) of the Provincial Administrative Court in Szczecin, II SA/Sz $1185 / 13$.

Judgment (2016) of the Provincial Administrative Court in Gdansk, III SA/Gd 744/16.

Aien, A., Rajabifard, A., Kalantari, M. \& Shojaei, D. (2015). Integrating Legal and Physical Dimensions of Urban Environments. ISPRS International Journal of GeoInformation. ISSN 2220-9964. 4, pp. 1442-1479; DOI:10.3390/ijgi4031442 
Balawejder, M., Adamczyk T. \& Cygan M. (2016). The problem of adjusting Polish spatial information resources to the standards of the Inspire. Geographic Information Systems Conference and Exhibition GIS ODYSSEY 2016, Conference Proceedings, 5th to 9th September 2016, Perugia, Italy. pp. 14-24.

Biłozor A. \& Renigier-Biłozor M. (2016). Procedure of Assessing Usefulness of the Land in The Process of Optimal Investment Location for Multi-Family Housing Function. Procedia Engineering. Volume 161, 2016, Pages 1868-1873. World Multidisciplinary Civil Engineering-Architecture-Urban Planning Symposium 2016, WMCAUS 2016. DOI: 10.1016/j.proeng.2016.08.720.

Buśko, M. (2014). Issues concerning disclosing useful functions of a building in cadastral documentation with respect to binding legal regulations. Przegląd Geodezyjny; ISSN 0033-2127. - 2014 R. 86 No. 6, pp. 3-8.

Buśko, M. (2015). Analysis of legal provisions regarding the determination of usable floor area of a building and living premises. Przegląd Geodezyjny; ISSN 00332127. 2015 R. 87 No. 12, pp. 8-12.

Çağdaş, V. (2013). An application domain extension to CityGML for immovable property taxation: A Turkish case study. Int. J. Appl. Earth Obs. Geoinf. 2013, 21, pp. 545-555.

Hanus, P. (2011). Analysis of circulation of information in local surveying documentation centre. Geomatics and Environmental Engineering; ISSN 18981135, 2011 vol. 5 no. 2, pp. 31-41.

Hanus, P., Hycner, R. \& Kwartnik-Pruc, A. (2013). Terminological analysis of selected problems of cadastre and homological subject. Pt. 1, Lot, boundary, real estate. Geodeta; ISSN 1234-5202. - 2013 No. 10, pp. 15-22.

Hanus, P., Hycner, R. \& Kwartnik-Pruc, A. (2013). Terminological analysis of selected problems of cadastre and homological subjects. Pt. 2, Directly to cadastre and surveyor. Geodeta; ISSN 1234-5202. - 2013 No. 11, pp. 25-32.

Inglot, A. \& Koziol, K. (2016). The Importance of Contextual Topology in the Process of Harmonization of the Spatial Databases on Example BDOT500. 2016 Baltic Geodetic Congress (BGC Geomatics). pp. 251-256.

Isikdag, U.; Horhammer, M.; Zlatanova, S.; Kathmann, R. \& Van Oosterom, P.J.M. (2014). Semantically rich 3D building and cadastral models for valuation. In Proceedings of 4th International Workshop on 3D Cadastres, Dubai, UAE, 9-11 November 2014; pp. 35-53.

Krzyżek, R. (2015). Innovative algorithm of vector translation method for the measurements of corners of building structures using RTN GNSS technology / Robert KRZYŻEK // Geomatics and Environmental Engineering; ISSN 1898-1135. 2015 vol. 9 No. 4, pp. 73-84. - Bibliogr. p. 84, Summ.

Lawendowicz, E. (2017). http://www.ela.mapa.net.pl/Prezentacje/cwicz-7-budynki.pdf access as of 15 March 2017.

Mika, M. (2016). Proposals for changes in surveying-legal procedures for the needs of cadastre in Poland. Reports on Geodesy and Geoinformatics vol. 102/2016; pp. 67-77 DOI: 10.1515/rgg-2016-0028

\section{Author:}

PhD Małgorzata Buśko, mbusko@agh.edu.pl

AGH University of Science and Technology

Al. Mickiewicza 30

30-059 Cracow, Poland 